\title{
Interfaces
}

\section{Everyday Photography? Politicizing a 'vernacular' photo album of the San Francisco Earthquake and Fire of 1906}

\section{Carolin Görgen}

\section{(2) OpenEdition}

\section{Journals}

Electronic version

URL: http://journals.openedition.org/interfaces/1458

DOI: 10.4000/interfaces. 1458

ISSN: 2647-6754

Publisher:

Université de Bourgogne, Université de Paris, College of the Holy Cross

\section{Printed version}

Date of publication: 15 December 2020

Number of pages: $29-51$

ISSN: $1164-6225$

\section{Electronic reference}

Carolin Görgen, «Everyday Photography? Politicizing a 'vernacular' photo album of the San Francisco Earthquake and Fire of 1906 », Interfaces [Online], 44 | 2020, Online since 15 December 2020, connection on 21 December 2020. URL : http://journals.openedition.org/interfaces/1458; DOI : https://doi.org/10.4000/interfaces.1458

\section{(c) (7)}

Les contenus de la revue Interfaces sont mis à disposition selon les termes de la Licence Creative Commons Attribution 4.0 International. 


\title{
EVERYDAY PHOTOGRAPHY? POLITICIZING A 'VERNACULAR' PHOTO ALBUM OF THE SAN FRANCISCO EARTHQUAKE AND FIRE OF 1906
}

\author{
Carolin Görgen \\ Sorbonne Université, HDEA
}

\begin{abstract}
The San Francisco earthquake and fire of 1906, defined as the most-photographed event of the early twentieth century, overlaps with the beginnings of vernacular photography. Drawing on the vast output of the disaster, this article politicizes the notion of the vernacular. As art institutions have championed an aestheticized vernacular, many anonymous photographs have been stripped off their sociopolitical context. A host of related practices, such as amateur or club photography, have thus become marginalized. This perspective has reinforced a narrative of American photography ca. 1900 as either "vernacular" or "high art." The heterogeneity of sources produced in San Francisco runs counter to this binary reading. They require a historiographical revision and a politicization of photo-collections. Exploring a personal photo album, this article retraces the visual, discursive, and material uses of "everyday" photography in extraordinary conditions. It points out how photo-practices were marked by extreme seismic events and domestic politics. The aim is two-fold: drawing attention to the complexity of archival materials and proposing a counter-narrative to the aestheticized vernacular.
\end{abstract}

Keywords: San Francisco earthquake and fire, photography in San Francisco, disaster photography, amateur photography, photo albums, history of California, California Historical Society, photographic archives, photographic materiality

Résumé: Le tremblement de terre et l'incendie de San Francisco en 1906, défini comme l'évènement le plus photographié du début du XXe siècle, coïncide avec les débuts de la photographie vernaculaire. En se basant sur la production engendrée par le désastre, cet article vise à politiser la notion du vernaculaire. Avec la mise en avant d'une esthétique vernaculaire, de nombreuses photographies anonymes ont été isolées du contexte sociopolitique. Tout un ensemble de pratiques, comme la photographie amateur ou collective, a ainsi été marginalisé. Cette perspective a renforcé une conceptualisation de la photographie américaine autour de 1900 comme étant soit "vernaculaire 》 soit " beaux-arts ». Le caractère hétérogène des sources produites à San Francisco contredit cette lecture binaire. Elles exigent une relecture historiographique et une politisation des collections photographiques. À partir d'un album photographique personnel, cet article retrace les usages visuels, discursifs et matériels de la photographie dite « de tous les jours » dans des conditions extraordinaires. Il montre comment les pratiques photographiques sont marquées par des séismes extrêmes et la politique locale. L'objectif sera à la fois d'attirer l'attention sur la complexité des matériaux dans les archives et de proposer une lecture qui évite l'esthétisation du vernaculaire.

Mots-clefs: tremblement de terre et incendie de San Francisco, photographie à San Francisco, photographie de catastrophe, photographie amateur, albums photo, histoire de la Californie, California Historical Society, archives photographiques, matérialité photographique 
In the early morning hours of April 18, 1906, the earth shook for about one minute in San Francisco. ${ }^{1}$ The earthquake, whose magnitude was later estimated at 7.9 on the Richter scale, caused numerous gas pipe leaks, so that by 5:30 a.m., more than fifty fires were reported. In the three days that followed, raging fires destroyed more than $75 \%$ of the city. While citizens had experienced numerous fires and earthquakes during San Francisco's brief existence as an American city - leading them to adopt a seal with a Phoenix rising from the ashes - the intense tremor and firestorms of April 1906 left more than half of the population, that is, some 250,000 people, homeless (Fradkin 8-12, 52-55, 179).

San Francisco, which by 1906 had become the nation's eighth largest city, boasted a thriving photographer scene at the time. Personal accounts suggest that a considerable amount of their work was destroyed as the city burned to the ground. A well-known practitioner such as Chinatown photographer Arnold Genthe watched his studio go up in flames (Genthe 87-97). The city's most prominent portrait photographer, Isaiah W. Taber, saw eighty tons of negatives disappear in the flames (Bonnet 142). Landscape

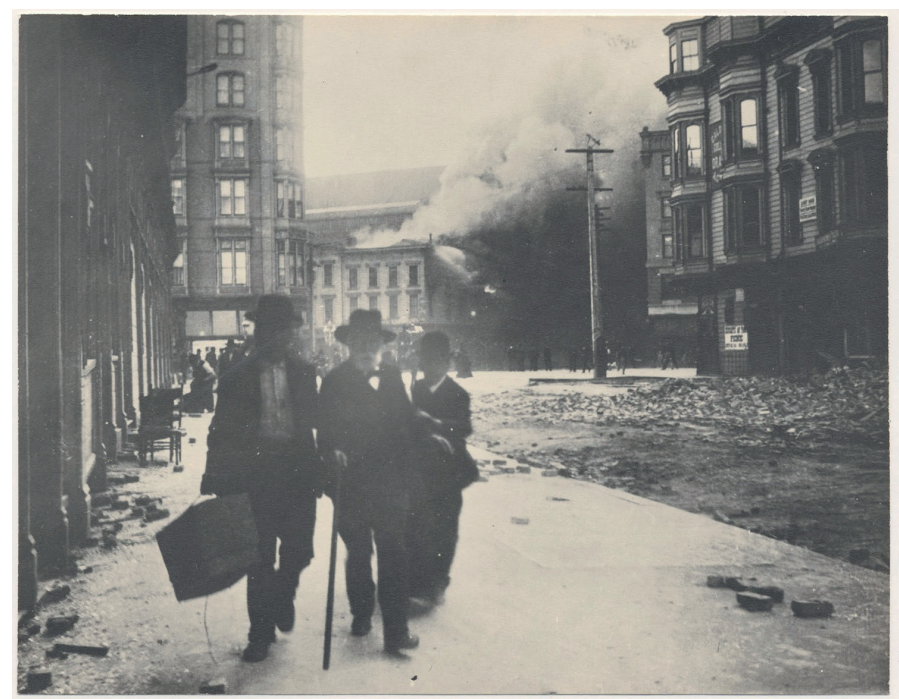

Figure 1. [unknown photographer], Carleton E. Watkins [with cane, during aftermath of earthquake], April 18, 1906, photographic print.

(C) The Bancroft Library Portrait Collection. The Bancroft Library, University of California, Berkeley.

1. This article is a revised and expanded version of a chapter from my dissertation (Görgen 2018). 
photographer Carleton Watkins, by then 76 years old and frail (Fig. 1), had to leave behind a collection of daguerreotypes and negatives which had been planned to be transferred to a new storage location a few days later (Palmquist 82-83). Editors at the San Francisco Call reported the losses of "priceless" material, stating that "[i]n all San Francisco there remain but a few hundred photographic negatives of the countless thousands taken of persons prominent here [...] for the past half-century" ("Priceless Negatives").

Despite these immense losses, the earthquake and fire gave way to an unprecedented image production. In 1905, the Eastman Kodak company had sold more than 1.2 million cameras (West 41). Given the company's large-scale production since the 1880s, historian Nick Yablon accordingly estimated that about one-third of the U.S. population could have owned a hand-held camera by the time of the disaster (214). Observations from a reporter of the Los Angeles Herald in San Francisco in May 1906 seem to corroborate this phenomenon:

The streets of the burned districts were thronged today with sightseers. Every train from neighboring towns on the peninsula and every ferryboat from the bay counties was packed with people eager to get their first glimpse of the city's devastation, and almost every third person carried a camera or a [K] odak. ("Dynamite Used")

This heightened demand on the supply market was echoed by the editors of Camera Craft, the city's photography magazine and mouthpiece of the local California Camera Club. Member Louis Stellmann reported that any photographic equipment "in Oakland, Berkeley and Alameda is sold or rented"(6), while his colleague Edgar Cohen summed up the situation as follows:

The probabilities are that never since cameras were first invented has there been such a large number in use at any one place as there has been in San Francisco since the $18^{\text {th }}$ of last April. Everyone who either possessed, could buy or borrow one, and was then fortunate enough to secure supplies for it, made more or less good use of his knowledge of photography. (183)

Today, the mass of this output can be consulted online thanks to the San Francisco Earthquake and Fire Project, launched on the centennial in 2006. It includes digitized photographs, albums, postcards, correspondence, and eyewitness accounts from six Californian institutions, including the Bancroft Library and the California Historical Society. Some 14,000 photographs - some authored, many anonymous - illustrate both the appeal of the destroyed city and reconstruction efforts. ${ }^{2}$

The 1906 San Francisco Earthquake and Fire Digital Archives Project, URL: https://bancroft.berkeley.edu/collections/ earthquakeandfire/index2.html (page accessed October 27, 2020) 
Facing this massive amount of material, the question of how to approach, contextualize, and analyze these sources imposes itself on photo-historical research. The sheer number of photographs seems to qualify this output as part of early twentieth-century "vernacular" photography, which was generated by the availability of Kodaks and increased free time. However, the San Francisco disaster photographs are anything but "snapshots capturing everyday life," as this genre is generally defined ("Vernacular Photography"). They were produced in a specific spatial, societal, and political context, and oftentimes used on carefully selected material supports. Research on early twentieth-century American photography has given little thought to these productions, as the canon is still mainly defined by an either-or approach - channeling archival sources either through the lens of fine-art photography, embodied by Alfred Stieglitz and the Photo-Secession, or as playful vernacular production. A cherrypicked selection of the latter has been on display in museums in recent decades. This binary approach has left little room for a thorough contextual reading of the archival bulk.

Against the background of the earthquake and fire, I will closely analyze an anonymous photograph album held at the California Historical Society - one of the oldest collecting institutions in San Francisco. Rather than producing spontaneous playful images, the maker of this album curated their own experience in an elaborate narrative sequence. This purposefully shaped photo-object therefore cannot be reduced to its formal or aesthetic qualities. Instead, its intimate testimony discloses the anxieties, questions, and material ways of dealing with the experience, which many official publication channels obfuscated. Focusing on this "anecdotal, individualistic" documentation will allow us to extract a local perspective of an uprooting event (Button 146-47). Photo albums are a decisive material support in the context of 1906 as they created a coherent narrative which could be recounted and inscribed into a larger communal context. As curator Mattie Boom rightly remarked, what historians have labeled "the iconography of everyday" is "not recorded" in photo albums $(124,126)$. Instead, what we see are exceptional moments - or in this case: disaster, dislocation, and death.

Through an outlook on the existing historiography and a close analysis of the album, the following article provides a critical methodological approach to anonymous photography sources of the 1900s and advocates in favor of a contextual understanding of these materials, beyond their tempting qualification as anonymous "vernacular." By exploring both the composition of the album and the tone that emerges from it, the aim is to uncover individual responses - visual and material - to the anything-but "everyday" circumstances of April 1906.

American photo-historical scholarship on the decades around 1900 is marked by two developments: on the one hand, researchers have cultivated an almost exclusive focus on Alfred Stieglitz 
and the New York Photo-Secession, whose broader circle has dominated literature since the 1970s and generates new scholarship up to this day. This selective interest in an avant-garde circle has turned Stieglitz into a "bibliographical monument," as François Brunet put it (264). While arguably necessary to the institutionalization of a photographic history, this approach has marginalized the more than ninety other American camera clubs which were active in the same period and whose productions reside in local archives across the U.S. - one major example being the California Camera Club which represented the largest organization in the U.S. with more than 400 members in 1900 (Görgen).

On the other hand, the mass of unknown photographs, produced through a Kodak leisure practice, has led to the rise of a selective snapshot aesthetic, which, similar to research on Stieglitz, is centered around formal aspects. This branch of vernacular photography, depicting the everyday in an aesthetically appealing way, has occupied an important place in photographic literature over the past thirty years (Levine and Snyder; Greenough et al.). As former SFMOMA curator Sandra Phillips explained regarding the mass of vernacular images:

I actually think that it's not going to be museums that will be savior of this stuff, it will be libraries that are interested in popular culture that will preserve this. The museum or gallery will just pick out what is intriguing artistically, but it won't save the whole thing ("Interview").

Yet, this exclusive interest in the "artistically intriguing" has come at the expense of a broader cultural-historical inquiry into the productions of this period - notably the ones which reside in libraries. Curator Mattie Boom recently voiced strong criticism of this conceptual reading. Noting that art history seems "at a loss as to what to do with amateur photography," she observed a disproportionate enthusiasm for the anonymous snapshot. As she put it: "it would seem, the more anonymous, the better" $(15,18)$. While many such images by unidentified authors appeal to the imagination of collectors and artists, she argues that one should instead conduct in-depth research on the production context, and if possible, the makers. A similar case is made for photo albums whose functions should be considered, instead of their formal characteristics (28).

As products of a new photography market in the early twentieth century, albums and their intimate depictions of family life have been re-appreciated by fine art institutions. Over the past twenty years, the album's material hybridity and its acts of spontaneous creation have been conceptualized as "a new genus of American folk artist[s]" (Snyder 25) - an approach inspired by the 1944 MoMA exhibition "The American Snapshot: An Exhibition of the Folk Art of the Camera" (Berger 38-40). Through its varied assemblage and formal coincidence, the snapshot family album came to be considered a precursor to avant-garde aesthetics. It was situated in a tradition of modern art "as [an] [object] of 
significant artistic merit" (25-27). While such framings recognized the materiality of the album, the source's historical depth and anchorage in a specific sociocultural context were oftentimes discarded.

The 2007 exhibition "The Art of the American Snapshot" at the National Gallery of Art has noted this inflation of the Kodak capture in twentieth-century modern art. In addition, the deliberate removal of the personal photograph from its original context facilitated its use as an individual specimen of a snapshot aesthetic. As "immensely satisfying visual objects," family photographs and their "accidental quality" became depersonalized items (Greenough et al., 2-5). Yet, as noted earlier by Sandra Philipps, since libraries and historical societies have large collections of such photographs, new research may be envisioned on the objects themselves, removed from the dominant art-historical narrative.

In the following analysis, I wish to rely on exactly this notion of the personal album as a social object. Mixing memories in images, texts, and other materials, albums are necessarily hybrid and therefore hardly fit into a generalized archival classification system, as Geoffrey Batchen remarked (81). If we focus on the interplay of diverse materials and uses in albums, as demonstrated by Elizabeth Siegel, Verna Curtis, and Martha Langford, they emerge as shapers of a collective imagination, and reveal their appeal, versatility, and function within a specific historical context.

In the months following the 1906 disaster, many albums combined commercially produced views and private photographs in a broader narrative sequence. This combination of public imagery and personal voice shows how the history of the event was negotiated in the pages of the album. The source thus turns from a standardized commodity into an individualized resource. These "album rituals," as Siegel called them, imply a collective, ceremonial dimension: they link the micro experiences of citizens to a larger community $(116,153)$.

What made the album attractive and useful in the wake of April 18, 1906 was its formal purity and originality. The tabula rasa of the album, "the whiteness of the sheet," invited the construction of narratives that filled the void of the pages (Langford 23). This aspect is even more tangible when applied to the destroyed city space, whose emptiness demanded to be filled. After the disaster, the album's blank spaces came to embody the city's devastated areas. The album fulfilled the double function of photographically reconstructing the event and representing a new material possession of one's own - after everything had been lost.

Individual disaster albums are an extremely valuable source as they run counter a victorious narrative which was rapidly disseminated in the summer of 1906 and would remain official history until the mid-twentieth century: as earthquakes were unpredictable, invisible events, many a politician, investor, and insurance company in California framed the event as another "great fire," which the city and the country had seen on numerous occasions, most notably in Chicago in 1871. Boosters of the American 
West, i.e. companies and individuals promoting the Western U.S. as a desirable place of settlement, would soon circulate "before and after" images of the city under construction and downplay the impact of the event on the Bay Area so as to incite investment. As Susanne Leikam put it, they created "an upbeat narrative of San Francisco's imminent cultural, economic, and political rise” (Leikam 2015, 244). Professional photographers and camera club members collaborating with city officials added to this localpatriotic depiction of a resilient pioneer city. They disseminated illustrated publications that documented the reconstruction effort, at times also in the shape of albums (Görgen 427-39). These sources were to predict the establishment of a new city in the making, for example in wide-angle shots of refugee camps in which cottages, infrastructure, and surrounding cityscape appeared orderly and intact (Fig. 2). Personal photo albums tell a different story - removed from flag-waving imagery and well-regulated rebuilding.

***



Figure 2. Charles Weidner, Camp 29, Mission Park, 1906, photographic print. BANC PIC 1994.022--ALB v.3:14.

(C) The Bancroft Library, University of California, Berkeley. 
Hybrid material sources, the personal albums of the 1906 disaster provide an ambiguous perception of the event - one in which feelings of loss, criticism of local politics, and reluctant participation in the booster narrative are combined all at once. One remarkable document in the collection of the California Historical Society (CHS), entitled Photograph Album No. 11, was donated in 1906. It was assembled by an unknown individual from San Francisco, one month after the disaster, and features twenty-five recto-verso pages with some fifty photographs, all of which are personal prints. The CHS holds a noteworthy collection of more than 200 albums, some ten of which cover the 1906 earthquake and fire. The given album was chosen as it is the only item that comprises a lengthy sequence of images by an anonymous photographer without additions of commercial images and was donated the same year as the disaster. While recent research on the event has paid attention to similar anonymous prints (Leikam 2015; Yablon), the album as historical source is mentioned only in passing. In the absence of a comprehensive inquiry into existing album collections, CHS's photograph album no. 11 provides a fruitful starting point for understanding the social function of these ordinary objects in extraordinary circumstances.

Starting with a short documentation of life in refugee camps, the album mainly consists of a walking tour through burned districts, documenting the damage of specific sites, including the neighborhood of the maker and public venues. The captions, short but effective, enrich the narrative sequence with nostalgic, at times political, but also outright sarcastic commentary.

The third photograph in the album is the first to depict people (Fig. 3). A family - father, mother, and daughter, alongside two women and a dog - are posing in front of a wooden shelter. While the family are seated for the photograph, the two women are standing at the entrance of the makeshift home, and seem engaged in some activity which they briefly interrupt for the time of the exposure. The family are rather well dressed - in striking contrast to the working attire of the two remaining women standing next to the erring dog. While the scene does not explicitly depict misery, it does suggest the hardships of daily life through the messy exterior. The division in two panels is underlined by the American flag, waving in the air behind the shelter. The experience of the portrayed people is connected to this national symbol in the caption, reading "The spirit of patriotism helps them to bear up happily after the great calamity." Through the wording, the viewer's gaze is directed toward the flag which stands as a reminder of durability. 


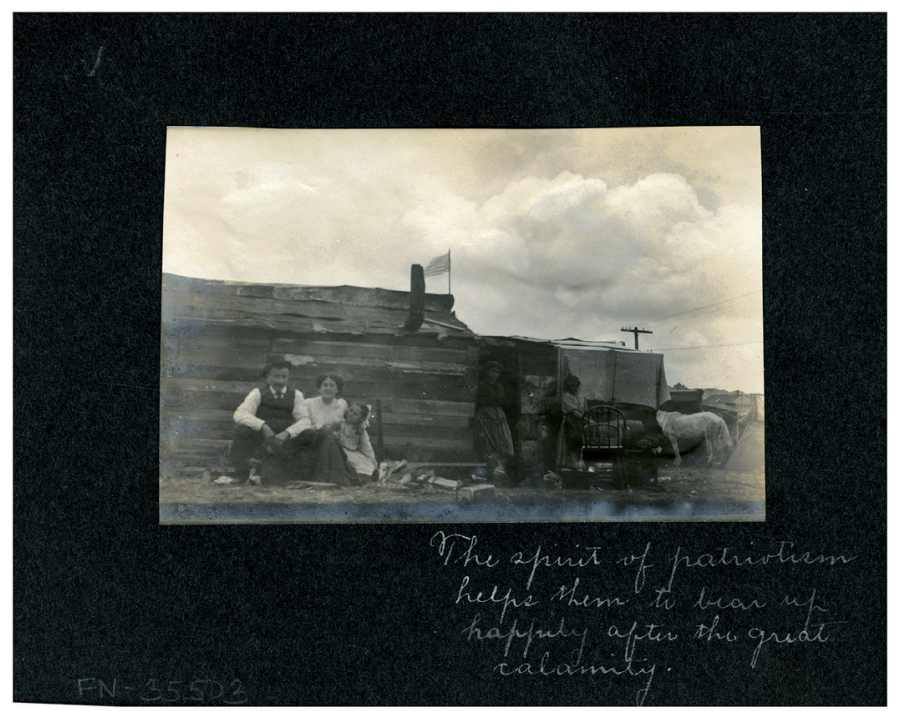

Figure 3. "The spirit of patriotism helps them to bear up happily after the great calamity." Visit to San Francisco a month after the earthquake and fire of April 18, 1906, photograph album.

(c) PC-PA: 011; California Historical Society.

The notion of national pride with which the image is instilled through the caption is reminiscent of the "official" portrayal of camp life. In publications from city officials, illustrated by professional photographers, citizens could be seen quietly enduring their new living conditions in a seemingly efficiently managed camp environment (Leikam 2015, 272-73; Görgen 428-34). While it can only be speculated to what extent the abstract principle of belief in the nation provided emotional relief, it did appear important for the maker of album no. 11 to align the people presented in the album as affiliates to this often-advertised "spirit" of the city, with which national values were closely entwined. It is a desired representation of the past as seen from a specific moment in the present - when the maker had found the time to engage materially with the experience by assembling the album. If we were to assume the maker to be the father or mother of the exposed family, the self-ascribed role as local patriots would constitute an important addition to the family narrative of the event. It allowed the compiler to shape an interpretation of the image which put its subject in the desired light. As Celia Lury has argued with regard to photographs in family albums: 
The photograph's freeze-framing creates a loop in time from which a newly self-possessed individual may emerge. In this loop, the future perfect of the photographic image - this will have been - may be suspended, manipulated and reworked to become a past perfected (85).

In this specific case, the polishing of the past by purposefully situating oneself within a wellknown event was extended by the positioning of the family photograph in the album. In the sequence, it is preceded by an image of "one of the well regulated streets in camp town," showing an orderly arrangement of white tents on an expansive field. Even though, visibly, the family's shelter was not located on this street, no comment is made about their own living conditions apart from patriotic references. The family portrait is followed by "some of the scenes of refugee life," depicting several men and a young girl (perhaps the daughter) engaged in discharging material from a trailer. Through this sequential depiction, the family's activities during the relief period are presented as contributions to reconstruction - by actively engaging in the daily work of the camp and keeping up the "spirit." In this context, the microscopic experience of one family, traumatic as it may have been, was adapted to a more broadly promoted, national optimism. At the outset of the album, these images seem to set the tone for its historical interpretation.

Yet, when leafing halfway through the pages, amid the walking tour of the urban ruins, the viewer is confronted with a more personal expression of the disaster experience. The return to oncefamiliar sites was an important, yet painful endeavor. A photograph captioned "Many times have we trodden this street" shows a cable car track leading up a hill, with bricks to one side and desolate façades to the other (Fig. 4). The only continuity that can be established with the past lies in the maker who, once again, treads the street - or what remains of it. The photographic tour continues in the same district, from a more distanced perspective, so as to depict the expanse of damage (Fig. 5). The earthquake and fire having razed to the ground practically all buildings, the map of the city lay bare and brought unexpected vistas to the fore, as confirmed by the caption: "It was very startling to see Russian Hill from Powell and Washington." In this confusing setup of a once well-known location, the photographer tries to make out specific points of reference like street names, repeated in the captions, in order to relocate themselves and the viewer of the album in the city space.

To affirm personal presence and to regain possession of the unfamiliar location, the compiler drew on a common motif of disaster albums, that is, portraits taken amid the rubble. This becomes tangible in a photograph captioned "Dear old 926," showing a woman standing next to what must be a completely torn down house (Fig. 6). While the debris occupies almost the entire foreground, the woman is depicted in a mourning posture with her head slightly bent and a book in her hand. Reminiscent of a funeral ceremony, the photograph positions her in front of the house as if she were standing at a 
Figure 4. "Many times have we trodden this street." Visit to San Francisco a month after the earthquake and fire of April 18, 1906, photograph album. (C) PC-PA: 011; California Historical Society.
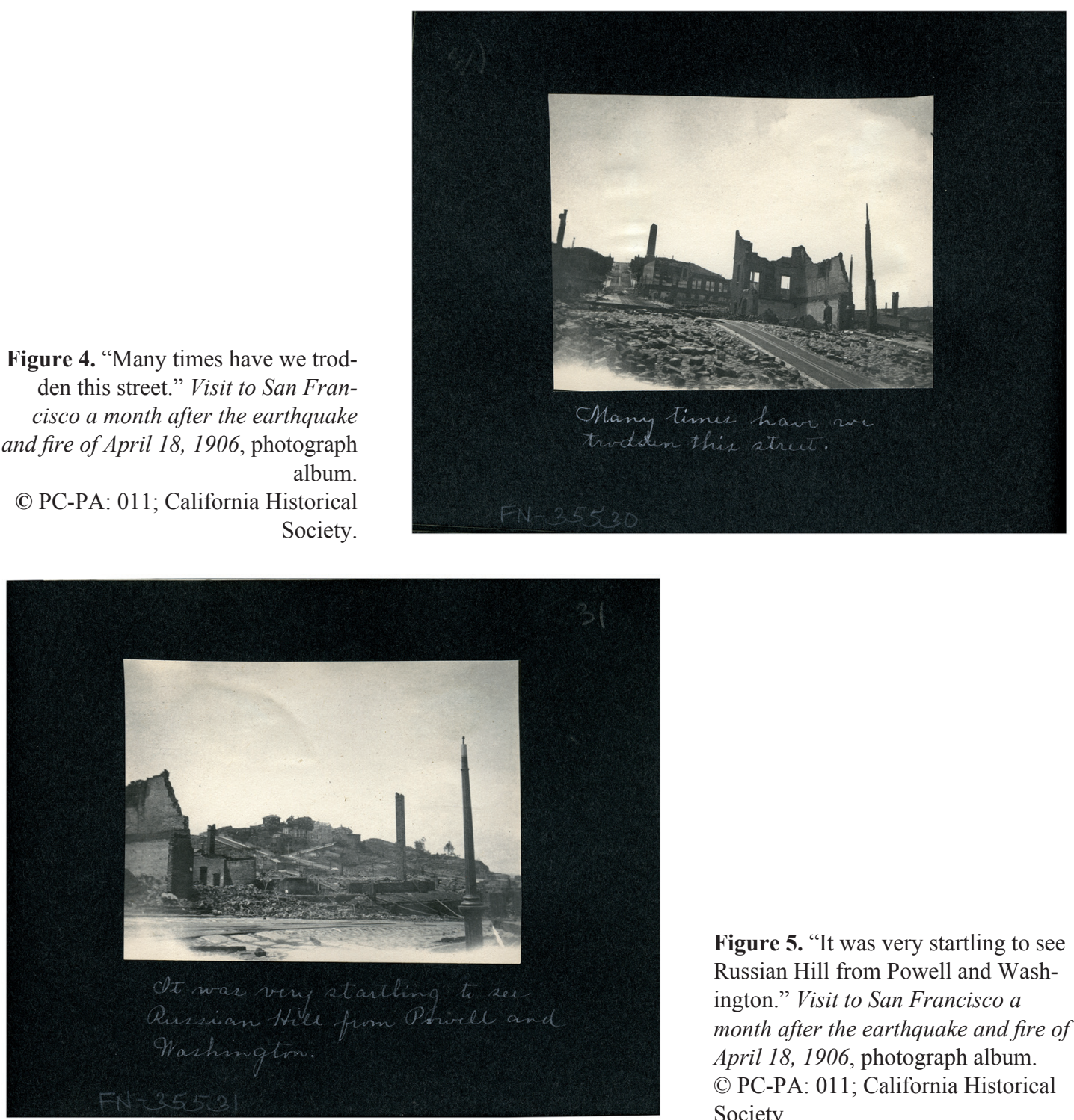

Figure 5. "It was very startling to see Russian Hill from Powell and Washington." Visit to San Francisco a month after the earthquake and fire of April 18, 1906, photograph album. (C) PC-PA: 011; California Historical Society. 
grave, paying her last respects to the dead. The caption, formulated like a personal address to a loved one, reinforces the impression of deep-felt loss.

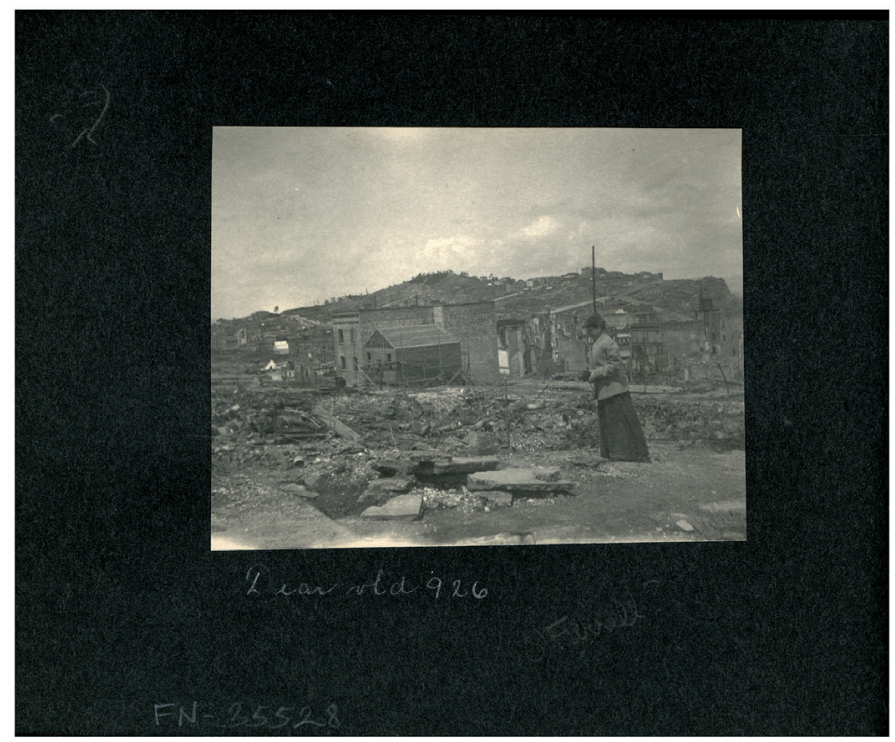

Figure 6. "Dear Old 926." Visit to San Francisco a month after the earthquake and fire of April 18, 1906, photograph album.

(C) PC-PA: 011; California Historical Society.

This explicit representation of grief is a hallmark of the personal album - as opposed to official illustrated publications. While some of the latter would allude to losses through ruined buildings, they were mostly devoid of people. As surviving inhabitants of the erased city, their presence in photographs disclosed misery and pain instead of resilience and optimism. However, the expression of grief was accepted within the viewing circle of an album who considered such personal documentation a necessity. To related viewers, the former no. 926 constituted a reference familiar to the point that it did not require an additional street name. The experienced loss could hence be more easily grasped when shared within this group.

Be it former homes or public buildings, situating a person within the unfamiliar space was a powerful tool to re-inscribe one's presence in the city. It can be understood as a photographic way of 
dealing with the situation by deliberately positioning one's body in relation to the city. In ascribing specific locations and dates to the scenes, "the continuity of time and place" was upheld, as Susanne Leikam has suggested, "despite the disruption of familiar structures and processes." It was the very format of the photographs which circulated from one hand to the next that helped in this process. Through a condensation of monumental damage, the destroyed scenery was "convert[ed] [...] into small, portable inanimate objects [through which] the sense of control over the events was established" (Leikam 2009). The narrative sequence of the album yet again contributed to this re-establishment of a coherent understanding of the event.

Another way of reaffirming a personal connection with the destroyed city setting was the use of political commentary. As San Francisco was well-known for its corrupt administration, the politicization of disaster imagery was not uncommon. Private photo albums which documented the damaged City Hall oftentimes alluded to the controversies related to its construction. As one caption from a photograph in the digital earthquake collection reads: "Ruins of San Francisco's twenty million dollar City Hall after the earthquake April 18, 1906. Twenty million dollar cost. Twenty years to build. Twenty seconds to destroy" (Calisphere). Construction on the edifice had started as early as 1870 , and by the time of its completion in 1899 , it had come to represent an inefficient, ostentatious urban elite, including mayor Eugene Schmitz who was in office during the earthquake and fire. In the wake of the disaster, some artistically inclined photographers aimed to "reclaim the civic authority" of the building, notably by zooming in on the building's Corinthian pillars - still standing amid the rubble (Yablon 231-34). Beyond such symbols reminiscent of ancient civilizations of the Mediterranean, many also desired to create an aesthetic urban vision. Amateur photographer and camera club member Edward N. Sewell, for example, depicted the two pillars of the entrance in soft hues, as though taking the viewer on a grand tour through a "fallen" city (Fig. 7).

While uninterested in the aesthetics of City Hall, the maker of album no. 11 did evoke the instructive value of the destroyed edifice. Yet, instead of seeking out picturesque ruins for future improvement, the photographer included what appears to be a quick snap of the scene from a distance, showing the

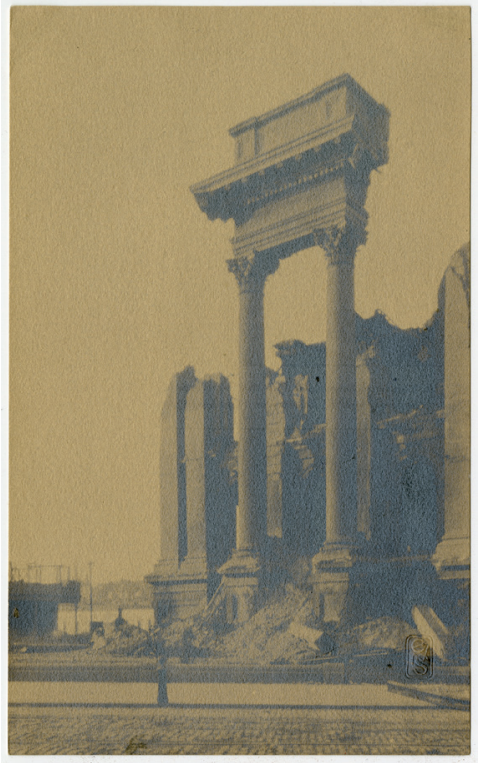

Figure 7. E.N. Sewell, City Hall, 1906, photographic print.

(C) California Historical Society. 
destroyed dome amid a veritable urban wasteland. The view "City Hall taken from Market Street" is captioned "A great example of corrupt ways" (Fig. 8). The image is not particularly well composed with its slightly slanted horizon and bulky pile of rubble in the foreground that obstructs a coherent view of the structure. As the only photograph of City Hall in the album, the compiler did not make any attempt to ennoble the building or to develop a fable of patriotism from its remnants, as official publications would do. Rather, through a brief glimpse at the site from a distance, City Hall was rapidly dismissed as an embodiment of fraud deserving rapid eradication.

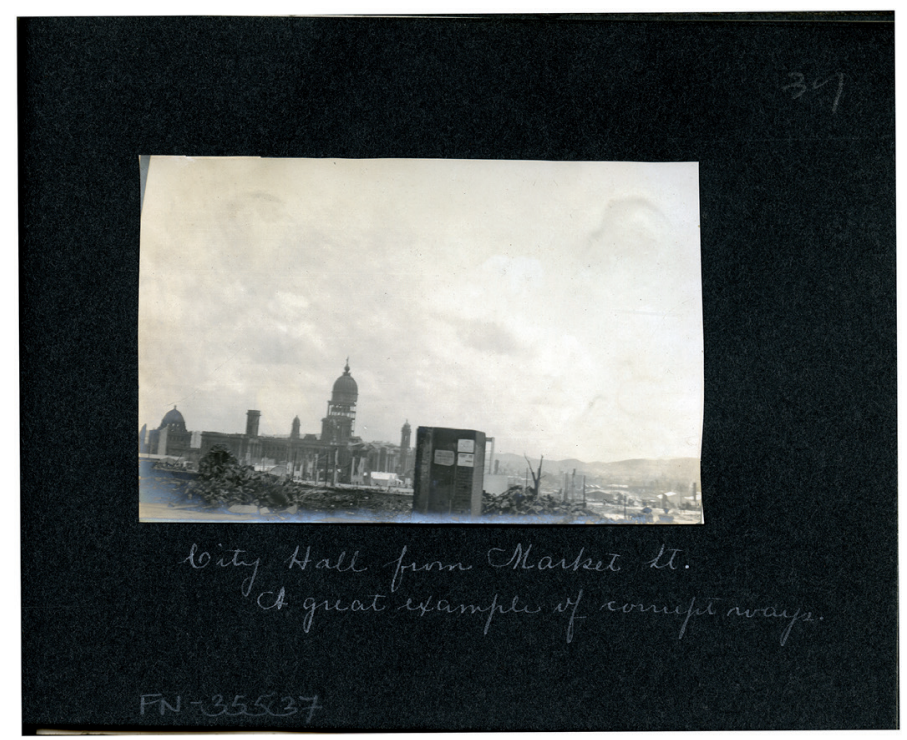

Figure 8. "City Hall from Market St. A great example of corrupt ways." Visit to San Francisco a month after the earthquake and fire of April 18, 1906, photograph album.

(C) PC-PA: 011; California Historical Society.

As the walking tour continues through the wealthy quarters on Nob Hill, more explicit political comment is made. Given the impact of business elites on urban decision-making, public aversions had been widespread since the 1870 s, not least since the mismanagement of City Hall. Oftentimes, this criticism was leveled at the wealthy neighborhood of Nob Hill, where the mansions of railroad magnates like Leland Stanford and Henry E. Huntington were located. On April 18, large portions of this 
district were destroyed (Fradkin 305-38). Official publications and many a camera club photographer, benefiting from the railroad and other local companies, then sought to frame the ruins as nostalgic sites of California's pioneering entrepreneurs. One such residency's ruin was renamed The Portals of the Past (Fig. 9). Built by Southern Pacific Railroad manager Alban N. Towne, the mansion had become well-known for its portico made of white marble. Unoccupied after Towne's death in 1896, the house continued to represent the style of "high art villas," much desired by the urban elite keen to stress San Francisco's cultural refinement (O'Brien). The architectural ruin of the Towne mansion consisted of ancient building and sculpture material instead of modern-day rubble. Its Greek design, which had endured seismic shock and firestorms, could be used to attest to this form of resilience. The fact that it had been inhabited by an early Californian entrepreneur added a layer of meaning to the optimistic account of an "American Mediterranean" (Starr 365) reconstructed after a catastrophe.

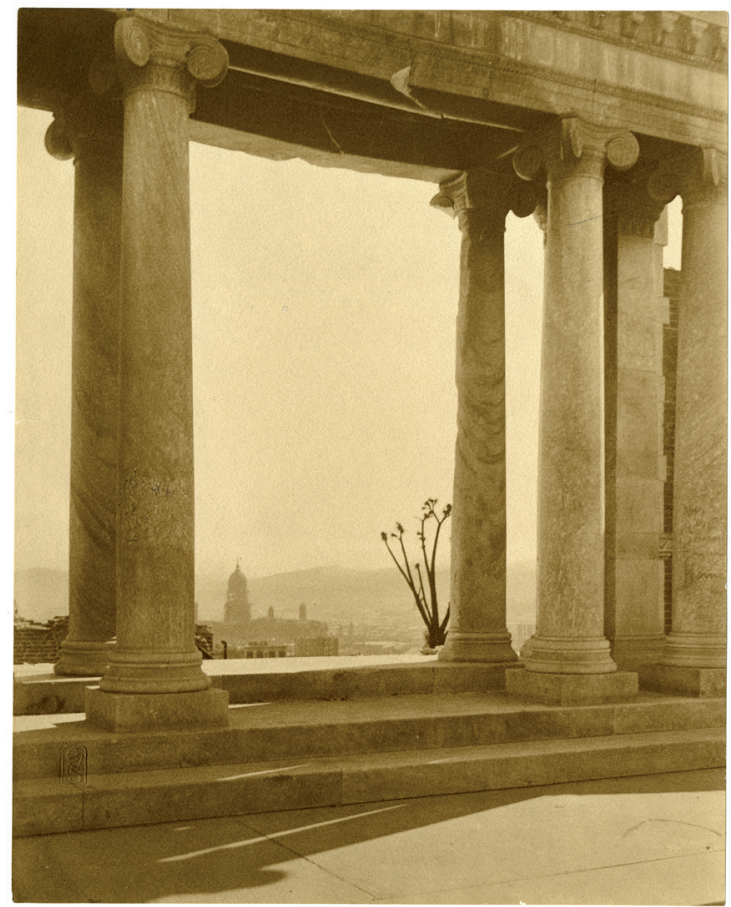

Figure 9. E.N. Sewell, Towne House, 1906, photographic print. (c) California Historical Society. 
Situated at the other hand of this representational spectrum, the maker of album no. 11 did not indulge in such transfigurations. A comprehensive view of Rudolph Spreckels's villa shows its neo-Gothic outer walls with hollow window frames, evidence of intense burning (Fig. 10). The son of Claus Spreckels and co-owner of his father's sugar refineries in California and Hawai'i, Rudolph Spreckels had speculated in real estate and belonged to the city's richest businessmen. The caption to the photograph of his Nob Hill home reads like a call for just treatment under disaster law, conveying a sense of satisfaction: "One time when money did not count. The offer of a million dollars by Spreckels to the firemen had no effect to save his mansion." With rumors of all kinds running high, Spreckels's apparent search for advantageous treatment to save his burning home provided a welcome anecdote to be added to the photograph.

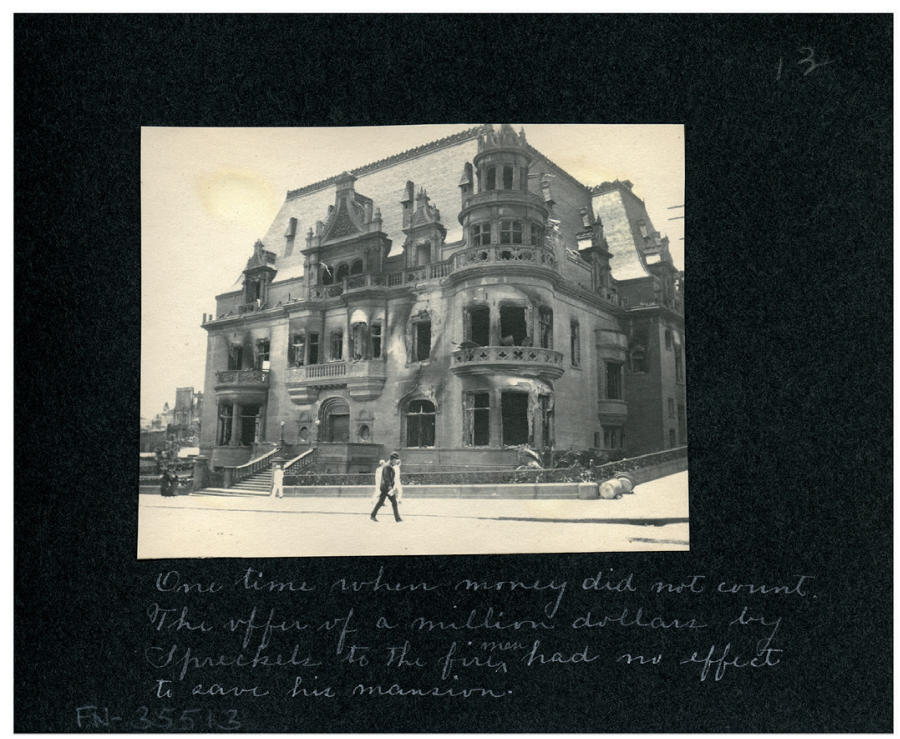

Figure 10. "One time when money did not count. The offer of a million dollars by Spreckels to the firemen had no effect to save his mansion." Visit to San Francisco a month after the earthquake and fire of April 18, 1906, photograph album.

(C) PC-PA: 011; California Historical Society. 
The mockery of business ventures becomes more tangible in the Nob Hill sequence of the album. An image of blatant destruction with two-thirds occupied by debris and garbage, and onethird in the background showing a decrepit structure, was captioned "Real estate is booming on Van Ness" (Fig. 11). A signpost lurking amid the rubble visually underlines the caption, suggesting that the destroyed terrain could be easily advertised for sale. Connecting debris with real estate, the album compiler sarcastically adopted the post-disaster booster rhetoric which jumped on seemingly vacant lots for promotion. In taking on this cartoonish tone, the voice grows increasingly political. The author draws attention to common practices of the time which allowed the rapid seizure of land by investors through facilitated building permits, although the sites had not been cleared and the risks not properly investigated (Davies 117). The album compiler thus also demonstrates a familiarity with comic images that were disseminated after the disaster in the shape of postcards and articles. These mocked the newly entrepreneurial "spirit" of San Francisco. Although the profession of the compiler is unknown, he or she must have felt the imminent threat to residential housing in the city, especially for working classes.

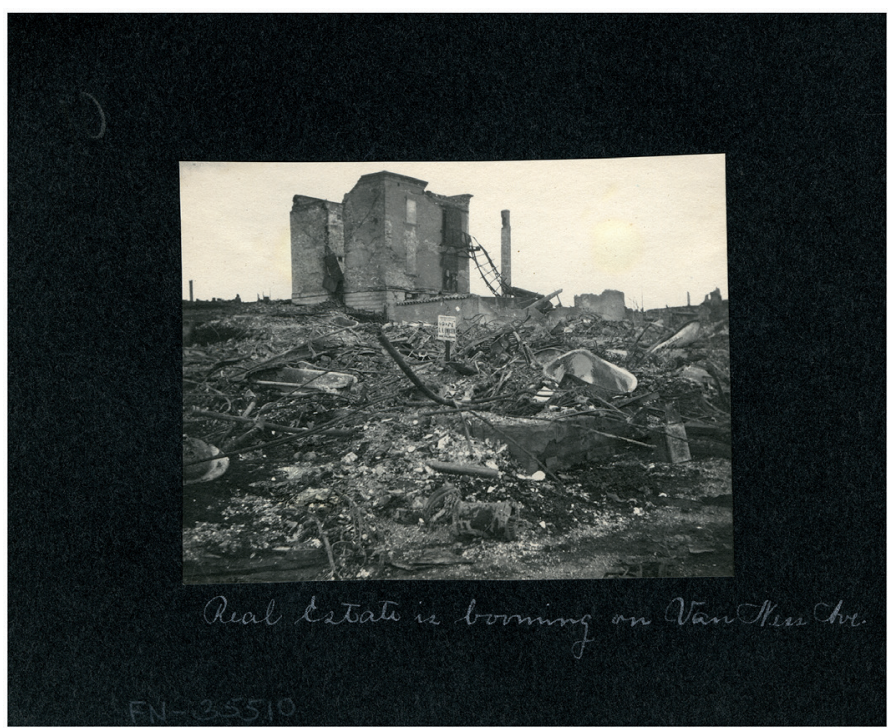

Figure 11. "Real estate is booming on Van Ness Ave." Visit to San Francisco a month after the earthquake and fire of April 18, 1906, photograph album.

(c) PC-PA: 011; California Historical Society. 
Many business and civic leaders, including aforementioned Spreckels and former mayor James Phelan, prioritized the removal of working-class neighborhoods, citing health risks. It has been shown, however, that these efforts on the part of the urban business and cultural elite served to boost investment in rebuilding, not to improve residential living conditions (Bolton and Unger). Inextricably tied to such efforts was the strategy of the city's board of real estate to downplay the earthquake and frame the catastrophe as a fire with minor consequences (Leikam 2015, 243-48). Again, professional photographers contributed to this effort by creating series of images that allowed readers of internationally circulating magazines like Sunset to retrace the reconstruction of dense neighborhoods like the Financial District and the waterfront (Fig. 12).

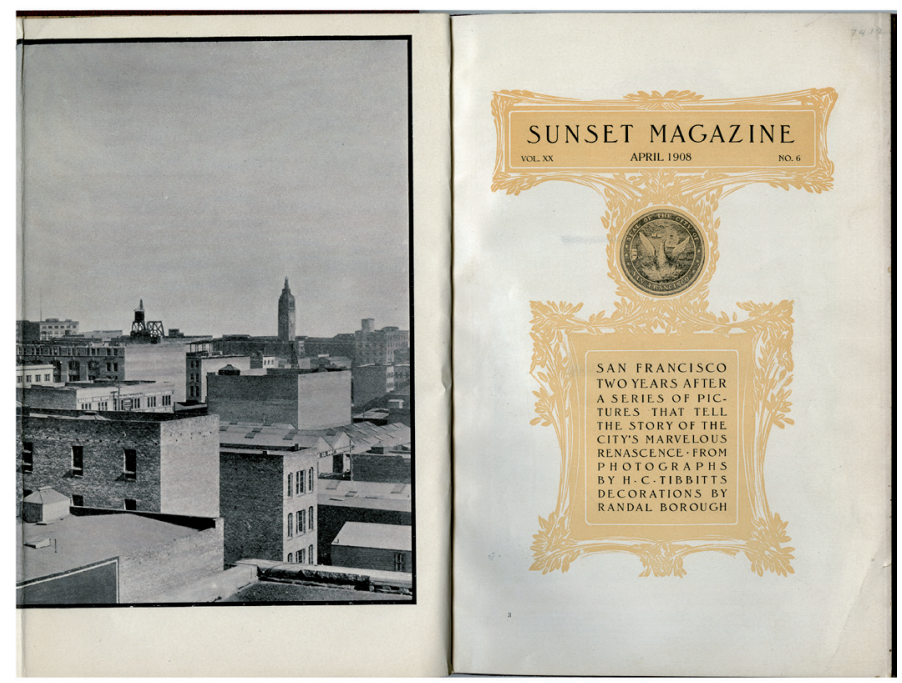

Figure 12. Howard C. Tibbitts, "San Francisco two years after. A series of pictures that tell the story of the city's marvelous renascence." Sunset 20:6 (April 1908).

(C) California Historical Society.

In speaking against the officialized optimism - be it through emotion or through mockery - the compiler of album no. 11 relied on their own voice as a local resident. The use of sarcasm and dark humor, especially when addressing housing problems, created an emotional detachment from the desolate scene. It was an explicit pointing of fingers at the wrongdoings of an ostentatious local 
administration. Through this politicization of space, the experience of destruction was re-channeled and allowed the maker to put personal losses into correlation with others.

The walking tour amid the ruins and refugee camps in this anonymous photo album documents the unstable social and political climate of San Francisco in 1906. Far from beautifying urban space, it clearly expresses the widely felt distrust in city officials dominated by corruption and speculation. In their blunt documentation of the destruction and the emotions attached to the losses, the narrator directly contradicts the jubilatory accounts which would be illustrated by professional and camera club photographers. Although the album does express a sense of local patriotism, notably at the beginning, it does not serve the common urban myth embodied by San Francisco's phoenix rising from the ashes. Neither aesthetic nor particularly playful, the album likewise counters the binary framing of turn-ofthe-century vernacular photography and shifts our attention toward local politics and living conditions.

With numerous albums in Californian collections revealing similar personal experiences in more or less elaborate ways (Görgen 403-38), the aim of this discussion was to underline the complexity of "vernacular" materials in photo archives of the 1900s and to attribute new agency to their compilers, albeit anonymous. Far from "everyday photography," these albums depict extraordinary moments in personal, communal, and national life. They are complex objects whose trajectories cross the private and the public realm. In their ambiguous narrative form, they provide a meaningful counterweight to the mass of photographs that tends to be sweepingly summarized as romantic ruin imagery, spectacular fire documentation, playful refugee-camp life, and optimistic rebuilding. As such, albums allow for an in-depth reflection on how citizens, who had just become accustomed to "everyday" photography in the shape of Kodak cameras, documented their lives amid the not-so-everyday circumstances they had to face in the spring of 1906.

In her extensive analysis of photographic albums, Martha Langford refers to Pierre Bourdieu's influential study Photography: A Middle-Brow Art (1965), in which he argues that many of these items did not "revolutionize society." Instead, they "reinforced and confirmed the middle class in its traditional values," and remained within a closed exchange circle of shared values and practices (25-27). This and many other anonymous albums treating the San Francisco earthquake and fire shed a more ambiguous light on Bourdieu's notion of conformity. On the one hand, as the compiler of album no. 11 amply demonstrated, they did not want to comply with the widely repeated chorus of a new San Francisco - hence also the absence of additional commercial images. Instead, the voice that emerges is marked by dislocation and loss, distrust and mockery, despite the hesitant optimism at the beginning. By disclosing the voice of the people, the album counters the standardized narrative and 
attributes historical importance to citizens - those living in refugee camps and returning to the ruins of their homes - as the donation of the album to the CHS in 1906 illustrates. On the other hand, despite its harsh criticism of the urban administration, the album cannot completely reverse the disaster narrative, as it was made within a specific context of white San Francisco (as the portrait in the camp shows) with rapid access to commodities like cameras and albums. In addition, none of the many disaster collections reveal how San Francisco's large Chinese community, whose entire neighborhood burned to the ground, experienced the aftermath with its intense racism and reinforced segregation. The same can be said of the city's small but existing African-American community which found shelter in otherwise all-white camps (Davies 194). These experiences are hidden, not only in official publications and personal albums, but also in the entire archival landscape (Leikam 2015, 305, 311-12).

As the rupture of life in the modern city came to coalesce with popular uses of the camera, photo albums assisted in reconstructing a bygone past, criticizing local officials, and envisioning a possible future for the community. In its pages, the popular understandings, convictions, and expectations of photographic materiality and representation are expressed (Edwards 222). These became all the more manifest in the face of immense material losses. When confronted with the photographic bulk of the 1906 catastrophe - despite its substantial number of prints, postcards, albums, and other material supports - it is not enough to simply engage with formal qualities and contents. Both the objects themselves, and the archival collections in which they are inserted, demand contextualization. Their makers may have been "everyday" practitioners. Yet they came to rely on their cameras in the extraordinary context of an urban, social, and political disaster, which had a tangible impact on their uses and thus shifts the common understanding of what 'vernacular' photography ca. 1900 entails. Future research should address the voices that emerge from the many neglected libraries where photo albums await recognition - some of them since 1906.

*This research was supported by the Terra Foundation for American Art and the Peter E. Palmquist Memorial Fund for Historical Photographic Research. The author thanks Frances Kaplan and Debra Kaufman at the California Historical Society for their invaluable assistance as well as two anonymous reviewers for their insightful comments. 


\section{Works Cited}

BATCHEN, Geoffrey. Forget Me Not: Photography and Remembrance. New York and Amsterdam: Princeton Architectural Press and Van Gogh Museum, 2004.

BERGER, Lynn. "The Authentic Amateur and the Democracy of Collecting Photographs." Photography \& Culture 2.1 (2009). URL: http://dx.doi.org/10.2752/175145209X419390 (page accessed October 27, 2020).

BOLTON, Marie and Nancy C. UNGER. "Housing Reconstruction after the Catastrophe: The Failed Promise of San Francisco's 1906 'Earthquake Cottages'.” Annales de Démographie Historique 120.2 (2010). URL: http://doi:10.3917/adh.120.0217 (page accessed October 27, 2020).

BONNET, Linda and Wayne. Taber: A Photographic Legacy. Sausalito: Windgate Press, 2004.

BOOM, Mattie. Everyone a Photographer: The Rise of Amateur Photography in the Netherlands, 1880-1940. Rotterdam and Amsterdam: NAI010 Publishers and Rijksmuseum, 2019.

BRUNET, François. The Birth of the Idea of Photography. Transl. Shane B. Lillis. Toronto and Cambridge, MA: Ryerson Image Center and MIT Press, 2019.

BUTTON, Gregory V. "Popular Media Reframing of Man-Made Disasters: A Cautionary Tale." Catastrophe and Culture: The Anthropology of Disaster. Eds. Susanna M. Hoffman and Anthony Oliver-Smith. Santa Fe and Oxford: School of American Research Press and James Currey Ltd., 2002. 143-158.

Calisphere. "Image / Ruins of San Francisco's twenty million dollar City Hall after the earthquake." URL: https://calisphere.org/item/ark:/13030/hb2q2nb2m8/(page accessed October 27, 2020).

COHEN, Edgar A. "With a Camera in San Francisco." Camera Craft 12.5 (1906): 183.

CURTIS, Verna Posever. Photographic Memory: The Album in the Age of Photography. New York and Washington: Aperture Foundation and Library of Congress, 2011.

DAVIES, Andrea Rees. Saving San Francisco: Relief and Recovery after the 1906 Disaster. Philadelphia: Temple University Press, 2012.

“Dynamite Used to Raze Walls.” Los Angeles Herald (May 7, 1906): 1.

EDWARDS, Elizabeth. "Photographs as Objects of Memory." Material Memories: Design and Evocation. Eds. Marius Kwint, Christopher Breward and Jeremy Aynsley. Oxford and New York: Berg, 1999. 221-236.

FRADKIN, Philip L. The Great Earthquake of Firestorms of 1906: How San Francisco Nearly Destroyed Itself. Berkeley: University of California Press, 2005.

GENTHE, Arnold. As I Remember. New York: Reynal \& Hitchcock, 1936. 
GÖRGEN, Carolin. “'Out here it is different': The California Camera Club and community imagination through collective photographic practices. Toward a critical historiography, 1890-1915.” PhD diss., Université Paris VII Denis Diderot and École du Louvre, 2018.

GREENOUGH, Sarah et al. The Art of the American Snapshot, 1888-1978: From the Collection of Robert E. Jackson. Princeton: Princeton University Press, 2007.

"Interview: Sandra Phillips, Senior Curator of Photography at the San Francisco Museum of Modern Art." PhotoWings. No date. URL: http://photowings.org/interview-sandra-phillips-senior-curator-of-photographyat-the-san-francisco-museum-of-modern-art/ (page accessed October 27, 2020).

LANGFORD, Martha. Suspended Conversations: The Afterlife of Memory in Photographic Albums. Montreal: McGill-Queen's University Press, 2001.

LEIKAM, Susanne. "Depicting 'Natural' Disasters in U.S.-American History and Culture: San Francisco's City Hall as an Icon of the 1906 Earthquake and Fire.” Copas 10 (2009). URL: http://dx.doi.org/10.5283/ copas.109 (page accessed October 27, 2020).

LEIKAM, Susanne. Framing Spaces in Motion: Tracing Visualizations of Earthquakes into Twentieth-century San Francisco. Heidelberg: Universitätsverlag Winter, 2015.

LEVINE, Barbara and Stephanie SNYDER, eds. Snapshot Chronicles: Inventing the American Photo Album. New York: Princeton Architectural Press, 2006.

LURY, Celia. Prosthetic Culture: Photography, Memory and Identity. London and New York: Routledge, 1998.

O'BRIEN, Robert. “The Portals of the Past." San Francisco Chronicle, September 8, 1948. File \#VMSF-0049 in The Virtual Museum of the City of San Francisco. URL: http://www.sfmuseum.net/hist12/portalsofthepast. html (page accessed October 27, 2020).

PALMQUIST, Peter. Carleton E. Watkins: Photographer of the American West. Fort Worth and Albuquerque: Amon Carter Museum and University of New Mexico Press, 1983.

“Priceless Negatives Destroyed by the Fire.” San Francisco Call (May 5, 1906): 11.

SIEGEL, Elizabeth. Galleries of Friendship and Fame: A History of Nineteenth-century American Photograph Albums. New Haven: Yale University Press, 2010.

SNYDER, Stephanie. "The Vernacular Photo Album: Its Origin and Genius.” Snapshot Chronicles: Inventing the American Photo Album. Eds. Barbara Levine and Stephanie Snyder. New York: Princeton Architectural Press, 2006. 25-33.

STARR, Kevin. Americans and the California Dream, 1850-1915. New York: Oxford University Press, 1973.

STELLMANN, Louis J. “Through the Ruins with a Premoette.” Camera Craft 14.1 (1907): 3-7. 
"Vernacular Photography." Museum of Modern Art, Collection Terms. URL: https://www.moma.org/collection/ terms/181 (page accessed October 27, 2020).

WEST, Nancy Martha. Kodak and the Lens of Nostalgia. Charlottesville: The University Press of Virginia, 2000.

YABLON, Nick. Untimely Ruins: An Archaeology of American Urban Modernity, 1819-1919. Chicago: The University of Chicago Press, 2009. 
